\title{
Perancangan Knowledge Management System Dosen untuk Menunjang Kurikulum Pembelajaran pada Mahasiswa di Institut Asia Malang
}

\author{
Bambang Tri Wahjo Utomo ${ }^{1}$, Abd Hadi \\ 1,2Institut Teknologi dan Bisnis Asia Malang \\ 1'bambangtriw@gmail.com, ${ }^{2}$ hadi0727@gmail.com
}

\begin{abstract}
ABSTRAK. Menjaga mutu pendidikan diperguruan tinggi adalah tugas pimpinan, pengelola dan dosen yang perlu dilengkapi dengan bidang keahlian dan pengetahuan yang memadai seperti halnya pemahaman mutu secara hakiki. Peran yang sangat penting salah satunya adalah menjaga kualitas sumberdaya manusia yang ada didalamnya yaitu dosen yang berfungsi untuk mentranfer bidang keilmuannya kepada mahasiswa. Profesi dosen sebagai peneliti dan pengajar yang mendampingi mahasiswa dalam mentransfer knowledge, maka sangat perlu untuk terus diasah serta dikembangkan bidang pengetahuannya dengan menerapkan knowledge sharing antar sesama dosen, sehingga akan memberikan nilai tambah, dan akan menjadikan mereka sebagai pembelajar sepanjang hayat (life-long learning). Sedangkan penerapkan knowledge sharing yang ada antar dosen hanya bersifat non formal, diskusi yang belum tersetruktur, meskipun sudah menerapkan pembentukan tim dosen pengelompokan matakuliah namun kenyataannya belum terlaksana dengan baik. Berdasarkan tujuan tersebut pembentukan tim pengelompokan matakuliah dimaksud dapat dirangkai dengan tepat sehingga membuat Knowladge Manangement System yang tepat guna bagi setiap dosen pengampu matakuliah. Dosen dapat mentranfer bidang keahlian dan penelitiannya kesesama, sehingga akan menghasilkan kurikulum pembelajaran yang kompeten untuk bekal mahasiswa mengambil matakuliah penjurusan di semester lima. Dalam penelitian ini akan dibangun sebuah Knowledge Management System dengan pendekatan SECI Model dan FGD yang akan diterapkan pada pembelajaran
\end{abstract}

Kata Kunci: Dosen ;Knowladge Manangement System; Matakuliah; SECI Model; Website

\begin{abstract}
Maintaining the quality of education in higher education is the task of leaders, managers and lecturers who need to be equipped with adequate fields of expertise and knowledge as well as an understanding of quality in essence. One very important role is to maintain the quality of the human resources in it, namely the lecturer whose function is to transfer their scientific fields to students. The profession of lecturers as researchers and teachers who accompany students in transferring knowledge, it is very necessary to continue to hone and develop their knowledge fields by implementing knowledge sharing between fellow lecturers, so that it will provide added value, and will make them as lifelong learners (life-long learning) ). Meanwhile, the application of existing knowledge sharing between lecturers is only non-formal, the discussion is not yet structured, even though it has implemented the formation of a lecturer team for subject grouping, in reality it has not been carried out well. Based on these objectives, the formation of the course grouping team can be assembled properly so as to create an appropriate Knowladge Management System for every lecturer who teaches the course. Lecturers can transfer their fields of expertise and research together, so that it will produce a competent learning curriculum to equip students to take majors in the fifth semester. In this study, a Knowledge Management System with the SECI Model and FGD approaches will be built which will be applied to learning.

Keywords: Lecturer; Knowladge Management System; Courses; SECI Model; Website
\end{abstract}

\section{PENDAHULUAN}

Institut Teknologi dan Bisnis Asia Malang merupakan salah satu kampus yang berada di Kota Malang dengan 2 fakultas dan 6 program studi yang dikelola. Seiring dengan perolehan mahasiswa yang semakin bertambah maka Institute Asia perlu untuk selalu meningkatkan rasio (kebidangan) dosen dalam melaksanakan pembelajaran terhadap mahasiwa khsusnya yang sudah mengambil matakuliah penjurusan tingkat akhir. Karena fungsi utama profesi seorang dosen adalah sebagian besar kegiatannya digunakan untuk mentranfer bidang keilmuan kepada mahasiswa. Sehingga akan menghasilkan mahasiswa yang memiliki kemampuan mandiri dengan mempunyai nilai tambah yang signifikan. Setiap bidang keahlian yang dosen berikan kepada mahasiswa akan memberikan nilai tambah, oleh karena itu dibutuhkan sebuah sistem yang dapat menjembatani antara sesama dosen berbasis Knowledge Management System (KMS). materi ajar yang tidak cocok mengadopsi konsep web-learning antara lain: materi yang bersifat hands on, seni musik khususnya mencipta 
lagu, interview skills, team work seperti marketing maupun materi yang membutuhkan pengungkapan ekspresi seperti $\operatorname{tarian}[5]$.

Knowledge adalah informasi yang dilengkapi dengan pemahaman pola hubungan dari informasi disertai pengalaman, baik individu maupun kelompok dalam organisasi. Knowledge merupakan penerapan informasi yang diyakini dapat langsung digunakan untuk mengambil suatu keputusan untuk bertindak [2]. KMS dosen ini menggunakan jenis penelitian deskriptif, yaitu jenis penelitian yang menggunakan cara untuk memecah atau menjawab setiap permasalahan yang sedang dihadapi sekarang berdasarkan tabulasi data, dan menganalisisa serta menginterpretasikan dengan tujuan untuk memecahkan setiap masalah secara sistematis dan faktual mengenai fakta-fakta dan sifat sifat populasi Transfer Knowledge sesama Dosen [1]. Pene;itian Deskriptif menggambarkan atau menguraikan tentang karakteristik dari suatu keadaan objek yang diteliti (KMS Dosen) [1]. Fungsi analisa deskriptif adalah untuk memberikan gambaran umum tentang data yang telah diperole. faktor-faktor yang menentukan dalam penerapan knowledge management system adanya tingkat keberhasilan 80\% dikarenakan adanya faktor budaya organisasi dan faktor SDM, serta factor $20 \%$ untuk teknologi KMS, Knowledge merupakan sumber daya strategis dan paling bernilai. Organisasi yang mempunyai banyak pengetahuan, perlu mengelola pengetahuan tersebut [2].

Penelitian dilakukan dengan perancangan model pembelajaran sesame Dosen untuk menunjang kurikulum belajar kepada mahasiswa di Institut Teknologi dan Bisnis Asia Malang yaitu berbasis Knowledge Management System (KMS). KMS ini diharapkan dapat mengakomodasi permasalahan dan kebutuhan informasi model pembelaran dosen. Salah satu jenis KMS yang dapat mengakomodasi permasalahan tersebut adalah KMS berbasis Website [3]. Dan akan memfokuskan pada knowledge sharing. KMS ini melakukan tabulasi sarana prasarana dan pengetahuan yang ada disetiap objek Dosen untuk meyiapkan kurikulum penjurusan mahasiswa [4], sehingga dosen akan lebih mudah mendapatkan informasi terkait objek update kurikulum sesama dosen yang ingin diwariskan. Selain itu, para dosen juga akan lebih mudah membagikan pengalamannya kepada dosen lain yang berbeda bidang keahliannya.

\section{METODE PENELITIAN}

Adapun metode penelitian yang digunakan dalam penelitian ini menggunakan perancangan sistem mengadopsi Knowledge Management Life Cycle (KMLC) [6]. Gambar. 1 merupakan tahapan yang dilakukan selama penelitian. Tahapan pada penelitian ini yaitu: studi literatur, mengevaluasi infrastruktur yang sudah ada, membentuk tim manajemen pengetahuan, menangkap pengetahuan, merancang prototype, dan menghasilkan prototype sistem Knowledge Management (KM).

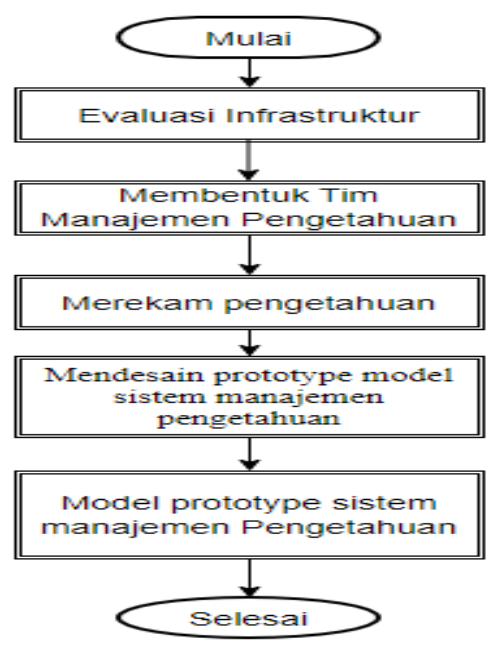

Gambar 1. Diagram Alur Penelitian

1. Evaluasi Infrastruktur yang ada merupakan komponen yang dilakukan untuk menentukan pemahaman terhadap komponen-komponen yang sesuai dengan strategis KM dan kerangka kerja teknologi. Kemudian dilakukan analisis terhadap infrastruktur penunjang, sehingga 
dapat mengenali kondisi minimal terhadap infrastruktur yang ada. Dengan demikian penulis memulai dengan membangun dan memanfaatkan fasilitas atau infrastruktur yang telah ada. Tahapan ini fokus pada, beberapa hal seperti dibawah ini.

- Memahami keadaan infrastruktur penunjang

- Memahami kerangka kerja teknologi

- Memahami keterbatasan implementasi dan

- Mengidentifikasi kesenjangan yang ada dalam infrastruktur teknologi.

2. Membentuk Tim Manajemen Pengetahuan yang akan membantu dalam melakukan perancangan, pembangunan, implementasi dan penempatan sesuai dari ketentuan KM. Perancangan tim yang efektif haruslah mempertimbangkan kemampuan stakeholder dari sumber daya internal maupun eksternal.

3. Menangkap / Merekam Pengetahuan dilakukan sebagai upaya untuk penangkapan pengetahuan yang dibutuhkan terkait pengembangan model sistem. Penangkapan pengetahuan dilakukan dengan teknik wawancara kepada pakar dan stakeholder terkait yaitu dosen. Selain itu, juga dilakukan observasi ke lapangan. Guna membagun pengetahuan yang didapat nantinya berupa pengetahuan tacit dan ekplisit. Pengetahuan tersebut kemudian dijadikan sebagai landasan dalam perancangan sistem KM.

4. Mendesain prototype model sistem manajemen pengetahuan Sistem yang dfrmengakomodir komunikasi antar stakeholder yang terlibat dalam sistem. Sharing pengetahuan dari setiap stakeholder dicatat dalam bentuk laporan yang dapat diakses oleh user yang memiliki wewenang terhadap informasi tersebut. Sistem tersebut dirancang dalam bentuk website, sehingga pihak eksternal maupun internal dapat mengakses informasi dan pengetahuan yang dibagikan oleh stakeholder pemilik pengetahuan.

5. Model Prototype KMS sebagai bahan pengembangan sistem dalam penelitian ini adalah untuk membangun KMS Dosen. Sistem ini nantinya diharapkan dapat digunakan untuk berbagi pengetahuan dibidang sharing pengetahuan sesama dosen segingga dapat meningkatkan kurikulum penjurusan dan menemukan hal hal yang baru untuk di manfaatkan mahasiswa tingkat akhir. Secara umum KMS ini memfasilitasi setiap stakeholder untuk saling berbagi pengetahuan.

\section{HASIL DAN PEMBAHASAN}

\section{Evaluasi Infrastruktur}

Tahapan analisis infrastruktur yang ada merupakan tahapan pemahaman komponen-komponen yang sesuai dengan strategi KM dan kerangka kerja teknologi, kemudian dilakukan analisis terhadap infrastruktur penunjang, keterbatasan implementasi, dan pengumpulan informasi terhadap pengetahuan yang mungkin bisa hilang. Selain itu, juga perlu mengetahui apakah lingkungan dapat menerima sistem KM. Pengumpulan data pada tahapan ini dilakukan dengan menggunakan kuesioner dan wawancara semi terstruktur.

Selain itu penulis juga melakukan pengumpulan data terkait penerimaan sistem KM dosen yang akan dibangun, sebanyak $81 \%$ dari 240 responden tenaga pendidik setuju dengan adanya sistem KM dosen. $81 \%$ tersebut sudah terbiasa berbagi pengetahuan di mana $65 \%$ dosen suka berbagi pengalaman mengajar, $32 \%$ dosen suka berbagi informasi terkait trick dalam merepresentasikan materi, dan $3 \%$ lebih suka berbagi informasi fasilitas pada objek penunjang.

\section{Pembentukan Tim KM}

Setelah melakukan evaluasi terhadap infrastruktur, tahapan selanjutnya adalah membentuk tim KM yang akan bekerjasama dalam membangun KMS Dosen ini.Pada tahapan ini dibentuk sebuah tim yang akan mengatur pengetahuan-pengetahuan yang ada. Tim KM ini terdiri dari: pemerintah sebagai pengawas, Wakil Rektor bid pendidikan, Kaprodi Teknik Informatika, Dekan, Wk Kaprodi, dan Tim pengampu matakuliah sebagai informasi dan memetakan fasilitas, Para Dosen pengampu matakuliah sebagai pemilik pengetahuan pengalaman

Tabel 1: Pembentukan Tim KM

\begin{tabular}{|l|l|l|l|l|l|l|l|l|l|l|}
\hline \multirow{3}{*}{ No } & \multicolumn{9}{|c|}{ Pemilik } & \multicolumn{3}{c|}{ Penyim-panan } \\
\cline { 3 - 10 } & Pengetahuan & PD & TP & KP & WK & PM & WR & BK & Hc & Sc \\
\hline
\end{tabular}




\begin{tabular}{|c|l|c|c|c|c|c|c|c|c|c|}
\hline 1 & Pengalaman & $\mathrm{X}$ & & & & & & & & \\
\hline 2 & Bidang keahlian & & $\mathrm{X}$ & & & & $\mathrm{X}$ & $\mathrm{X}$ & $\mathrm{X}$ & $\mathrm{X}$ \\
\hline 3 & Riwayat Mengajar & & $\mathrm{X}$ & & & & & & $\mathrm{X}$ & $\mathrm{X}$ \\
\hline 4 & Riwayat Penelitian & & & & $\mathrm{X}$ & & $\mathrm{X}$ & & $\mathrm{X}$ & $\mathrm{X}$ \\
\hline 5 & Ide dan Inovasi & & $\mathrm{X}$ & $\mathrm{X}$ & & $\mathrm{X}$ & & & $\mathrm{X}$ & $\mathrm{X}$ \\
\hline 6 & $\begin{array}{l}\text { Tim Pengampu } \\
\text { Mayakuliah }\end{array}$ & & $\mathrm{X}$ & & & & $\mathrm{X}$ & $\mathrm{X}$ & $\mathrm{X}$ & $\mathrm{X}$ \\
\hline 7 & Daftar Hadir & $\mathrm{X}$ & $\mathrm{X}$ & $\mathrm{X}$ & $\mathrm{X}$ & $\mathrm{X}$ & $\mathrm{X}$ & $\mathrm{X}$ & $\mathrm{X}$ & $\mathrm{X}$ \\
\hline
\end{tabular}

Keterangan:

PD: Para dosen

TP: Tim Matakuliah

WK: Wakil Rektor

KP: Kaprodi

PM: Pemerintah

WKP: Wakil Kaprodi

DK: Dekan

Hc : Hard Copy

Sc : Softcopy

\section{Perancangan Blueprint}

Analisis Kebutuhan Fungsional Hasil dari pengumpulan informasi terkait sumber pengetahuan dari stakeholder yang menjadi responden maka ada beberapa kebutuhan fungsional yang perlu dibangun pada sistem KM ini. Kebutuhan fungsional meliputi beberapa fungsi sebagai berikut, yaitu

- $\quad$ Fitur share dan Event: Fitur ini memfasilitasi semua user yang sudah terverifikasi untuk dapat membuat konten dan event yang akan dilaksanakan, dan kemudian dibagikan kepada user yang lain

- $\quad$ Fitur Forum dan Diskusi: Fitur ini digunakan oleh user untuk saling berinteraksi dengan melakukan diskusi terkait trik mengajar, trik upgrated knowlage, ide kurikulum, yang diangap penting dan berpengaruh pada perbaikan kualitas para dosen.

- $\quad$ Fitur Profile Dosen : Profile dosen dan keahlian akan berguna untuk identitas dan riwayat keahlian dan pengampu matakuliah penjurusan

- Fitur Update Kurikulum pembelajaran internal, membahas mengenai Ide terbaru, pembaharuan kurikulum, teknik pengejaran dan praktikum

\section{Perancangan Sistem Usecase}

Usecase menggambarkan pengguna atau yang dikenal dengan aktor siapa saja yang dapat berinteraksi dengan sistem dan apa saja yang dapat dilakukan oleh aktortersebut. Aktor dan deskripsi pada sistem ini dapat dilihat pada Error! Referencesource not found.

Usecase ini menggambarkan fungsionalitas dari sistem manajemen pengetahuan Dosen yang dibangun dan interaksi antara aktor dengan sistem. Pada sistem ini terdiri dari 2 aktor yaitu admistrator, pengelola objek kms Dosen, Setiap actor memiliki peranan masing masing. Scenario usecase yang menggambarkan alur jalannya proses usecase dari sisi aktor dan sistem dapat dilihat pada Gambar. 2 


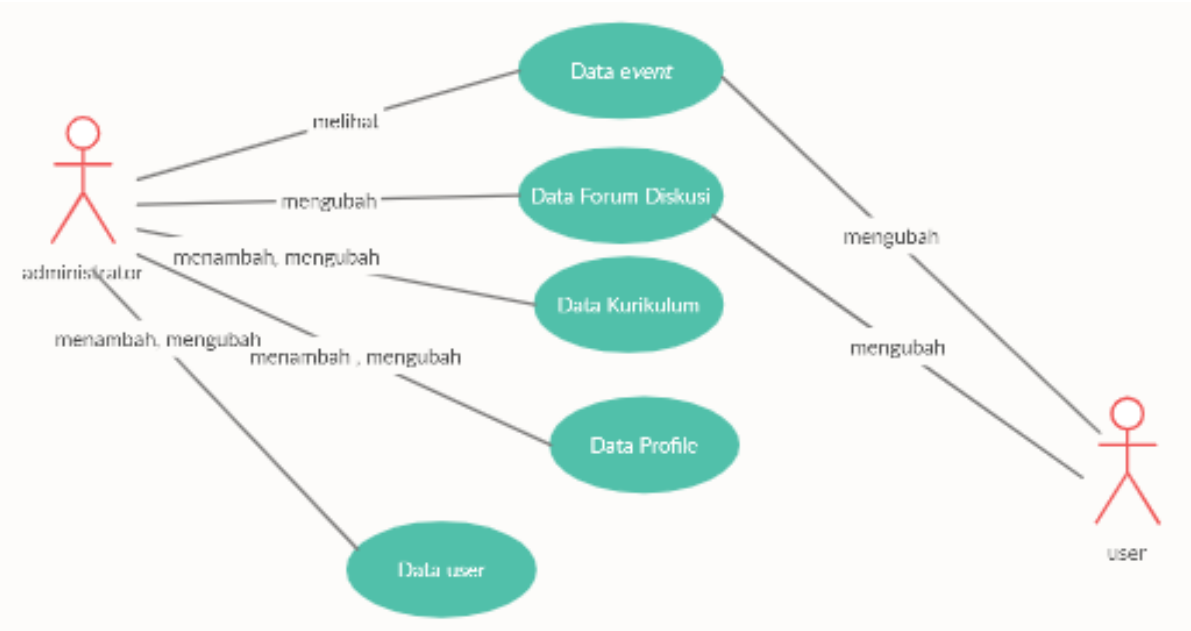

\section{Perancangan Interface}

Gambar 2. Usecase Diagram sistem

Perancangan prototype Interface berfokus pada konsistensi, relevansi, navigasi dan kegunaan fungsi. Berikut beberapa model Interface yang dirancang untuk memenuhi kebutuhan user pada sistem adalah terdapat pada Gambar. 3

KMS Dosen Institut Asia Share dan Event $\quad$ Forum dan Diskusi Profile Dosen Update Kurikulum More

\section{Selamat datang}

we learn together

Kunjungi situs belajar bersama ini untuk menunjang kurikulum dan ke ahlian mengajar

Gambar 3. Interface halaman Utama 
Pada halaman utama menampilkan beberapa fitur KMS dosen terdiri dari share dan event, forum diskusi, Profile dosen, update kurikulum sehingga dapat mempermudah user untuk mengakses dan menggunakap system ini. Informasi share dan Event berisi form konten bagi para dosen untuk memuat dan memulai diskusi, barik berupa materi artikel kuliah dan books terupdate. Selanjutnya adalah tampilan form untuk membuat/menulis artikel yang bertujuan untuk membagikan pengetahuan yang dimiliki oleh user sistem yang terlihat pada Gambar. 4

Gambar 4. share dan Event

\section{KESIMPULAN}

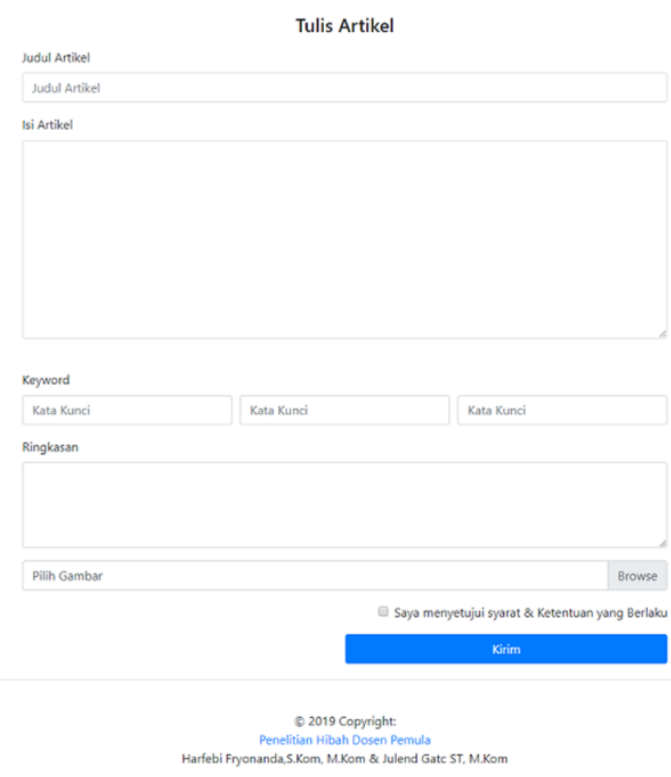

1. Dengan adanya KMS Dosen dapat menjadi sarana penunjang berbagi pengetahuan dan pengalaman tiap tiap dosen

2. Lembaga menginginkan adanya koordinasi setiap stakeholder dalam mentranfer bidang keilmuannya.

3. Dengan adanya KMS Dosen diharapkan para dosen dan pengajar pada umumnya mempunyai bekal dan inovasi yang lebih terarah untuk menunjang kurikulum penjurusan,

\section{UCAPAN TERIMAKASIH}

Riset penulis dibiayai oleh Hibah Penelitian Dosen Pemula dari DRPM RISTEKDIKTI dengan kontrak No. 083/SP2H/LT/DPRM/2020, tanggal 9 Maret 2020

\section{DAFTAR RUJUKAN}

1. Lestari Wiji Endah. 2018. Prototipe Knowledge Management System Sebagai Media Pembelajaran Distance Learning Dengan Pendekatan SECI Dan MVC. Jurnal Komputer dan Informatika Volume XX No. 2.

2. Yudha Bramanta. 2015. Kajian Penerapan Knowledge Management System Berbasis Seci Model Dalam Format E-Mobile: Studi Kasus Universitas Indraprasta Pgri. Jurnal Faktor Exacta 8(3): 279-289.

3. Herlinda 2017. Prototipe Web Kms Pada Universitas Sebagai Sarana Komunikasi Dosen Dengan Kerangka Kerja "Tiwana". Jurnal String, Vol.1, No.3

4. Yandi Mohammad. 2015. Implementasi Seci Model Pada Penerapan Knowledge management System.Seminar Nasional Teknologi Informasi dan Multimedia 2015.

5. Sulaiman Han. 2015. Knowledge Management System Service Center Berbasis Web. Jurnal Faktor Exacta 8(3): 220-230.

6. E. M. Awad and H. M. Ghaziri, Knowledge Manajement, Second. Delhi: Sareen Printing Press, 2010. 